\title{
Determinants of Capital Structure and Testing of Applicable Theories: Evidence from Pharmaceutical Firms of Bangladesh
}

\author{
Md. Farhan Imtiaz ${ }^{1}$, Khaled Mahmud ${ }^{1} \&$ Avijit Mallik $^{2}$ \\ ${ }^{1}$ Institute of Business Administration, University of Dhaka, Bangladesh \\ ${ }^{2}$ United International University, Bangladesh \\ Correspondence: Khaled Mahmud, Institute of Business Administration, University of Dhaka, Bangladesh. \\ E-mail: khaled@iba-du.edu
}

Received: December 11, 2015

Accepted: February 15, 2016

Online Published: February 25, 2016

doi:10.5539/ijef.v8n3p23

URL: http://dx.doi.org/10.5539/ijef.v8n3p23

\begin{abstract}
The objectives of this paper are to determine the significant factors that affect the capital structure of listed pharmaceutical firms in Bangladesh and to test the capital structure theories. To achieve the intended objectives a panel dataset including 8 major pharmaceutical firms were taken over the time period from 2009 to 2013 . The collected data were analyzed by employing correlated panels corrected standard error model using six variables i.e. profitability, tangibility, growth, size, liquidity and operating leverage. Among the 6 variables tangibility, profitability and operating leverage were found to be statistically significant determinants of capital structure. Profitability, tangibility, growth and operating leverage are negatively related to the capital structure while size and liquidity are positively related to the capital structure of the pharmaceutical firms of Bangladesh. The empirical analysis finds that the static trade-off theory and the pecking order theory are the most dominant capital structure theories for the pharmaceutical firms of Bangladesh. These factors must be considered by the financial manager to determine the appropriate capital structure for the company to maximize value of the firm.
\end{abstract}

Keywords: capital structure, trade-off theory, pecking order theory, agency cost theory, leverage, pharmaceutical firms, Bangladesh

\section{Introduction}

According to capital structure theory, firms determine a target debt ratio which is based on a trade-off between the costs and benefits of debt and equity. How an organization is financed is important to both the managers of firms and suppliers of funds. This is because if finance mix is wrong, then the performance and survival of the business firms may be seriously affected. Therefore, the purpose of this study was to examine the relationship between leverage and determinants of capital structure decision of pharmaceuticals firms in Bangladesh.

In order to achieve the objective of this study the data related to a documentary analysis which is necessary for this study were gathered from the financial statements of 8 firms for five consecutive years (2009-2013), mainly from audited balance sheet and income statement. Finally, the study analyzes the results using both descriptive and inferential statistics. Since the phenomenal work of Modigliani and Miller (1958), what determines firms' choices of capital structure has been a major question in the field of corporate finance. Since then, a good number of studies have been conducted in both developed and developing countries in order to identify those factors that have an effect on firms' choice of capital structure. Given the amount of empirical literature available on the topic of this research and the time constraint, it would have been very difficult to present the results of all the studies. Therefore the review of the empirical studies in this paper on the determinants of capital structure decision has a particular focus on those studies that have been conducted since the 1990s.

The paper is organized in 5 sections where 1st section gives an idea of background of the study. Section 2 discusses different capital structure theories and capital structure patterns from different empirical studies. Section 3 discusses about research methodology and model specification. Section 4 shows the results of empirical analysis while section 5 concludes the paper.

\section{Literature Review}

The literature shows a number of different theories regarding capital structure. Modigliani and Miller (MM) proposition, static trade of theory, agency cost theory and pecking order theory are some of the prominent 
theories of capital structure. According to Modigliani and Miller (MM), the value of the firm is independent of the capital structure under the assumption of perfect capital market. The firm's value is determined by its real asset, and pure capital structure management cannot change it. Myers and Majluf (1984) developed pecking order theory which stated that firms should follow an order to finance new type of investment. Firms first finance new investment opportunities internally, then with debt which is less risky and finally with equity if required. According to Jensen (1976), a finance manager should determine the capital structure considering both the agency cost of debt issue and agency cost of equity issue. This is known as agency cost theory of capital structure.

There are a large number of potential factors that may have an impact on leverage ratio. These factors include size of the firm, tangibility, profitability, growth, liquidity and operating leverage. It is expected that profitability, liquidity and operating leverage are negatively related with capital structure (leverage), while tangibility, growth and size are positively related with leverage.

Rajon and Zingles (1995) conducted a study to see if the factors affecting the capital structure are similar for US companies and other developed countries. They concluded that the factors are similar across G-7 countries and US, but firm size is not a significant determinant of leverage for these countries.

Booth et al. (2001) examined the factors of capital structure across developing \& developed countries. The study shows that the factors are similar \& they affect the capital structure in a similar way for both developed and developing countries. However they also observed that the long term debt ratios of developed countries were relatively higher. Buferna et al. (2005) provided further evidence of the capital structure theories relating to a developing country and examined the impact of different firm specific variables on the capital structure of the Libyan business environment. They developed four explanatory variables that represent profitability, growth, tangibility and size to test their relation to leverage. The results showed that both the agency cost theory and the static trade of theory are the most dominant theories to explain the capital structure of Libyan companies.

Amidu (2007) conducted a study on Ghanayan banks to investigate the factors that affect the capital structure of these banks. The study reveals that there is positive relation between short term debt and bank size, growth and tax but negative relation between short term debt and profitability, asset structure and risk of banks. On the other hand, there exists a positive relation between long term debt ratio \& asset structure, profitability but a negative relation between long term debt ratio and size, bank risk, growth \& tax. The results were supported by pecking order \& static trade-off theory.

Chowdhury, MU (2004) in his empirical study focused on agency cost model of capital structure of Japanese and Bangladeshi firms to evaluate the cross-sectional differences in leverage ratios. The study showed that due to institutional differences the agency structures of Japan and Bangladesh are different. Japanese firms exert better corporate governance system to lessen the conflicts between stockholders and managers \& the conflicts between stockholders and debt holders which in effect reduce the agency costs of debt and agency costs of equity. Lima, M (2009) investigated the factors that affect the capital structure of Bangladeshi pharmaceutical firms and the applicable capital structure theories in this context. She took six variables i.e: operating leverage, growth rate, tangibility, agency cost of equity, bankruptcy risk \& debt service capacity. In her study all the variables were found statistically significant. While operating leverage, growth rate, debt service capacity and tangibility were positively related to capital structure, bankruptcy risk and agency cost of equity were negatively related to debt ratios.

Sayeed, MA (2011) used cross section random effects model for panel data to explore the determinants of capital structures of selected Bangladeshi listed companies. Agency cost (negative effect on leverage), tax rate (positive effect), debt tax shields such as depreciations (negative effect), firm size (positive effect), collateral value of assets (positive effect) were found to be the significant factors affecting capital structure.

Siddiqui, SS (2012) examined the importance of 8 factors in the capital structure decisions of Non-bank Financial Institutions in Bangladesh. It was found that factors such as debt service coverage, liquidity ratio, and growth rate, operating leverage, firm size and age of the firm had significant influences on the capital structure of Bangladeshi NBFIs.

\section{Research Methodology and Model Specification}

\subsection{Sample Design}

The population of the study is all pharmaceuticals firms in Bangladesh. For this study, five years data (2009-2013) will be considered. Therefore, 8 firms which have financial statements for the year, 2009, and onwards are incorporated in this study. The firms are chosen on the basis of their market size. 


\subsection{Statement Hypothesis}

This study is intended to examine the relationship between leverage and firm specific (profitability, tangibility, growth, size, liquidity and operating leverage) determinants of capital structure decision and to understand about theories of capital structure that can explain the capital structure of pharmaceutical industry in Bangladesh.

In order to achieve the objective of the study, six hypotheses (HP) were developed as shown below.

\section{What determine the capital structure of pharmaceutical firms in Bangladesh?}

HP 1: There is no relationship between leverage ratios and profitability.

HP 2: There is no relationship between leverage ratios and growth.

HP 3: There is no relationship between leverage ratios and tangibility.

HP 4: There is no relationship between leverage ratios and liquidity.

HP 5: There is no relationship between leverage ratios and size.

HP 6: There is no relationship between leverage ratios and operating leverage.

\subsection{Model Specification}

Both descriptive and inferential statistics were used to analyze the data collected through document review. Descriptive statistics of the variables and different percentiles of the dependent variable were calculated over the sample period. In addition, correlation matrix was used to identify the relationship of each variable among them and with dependent variable. Then, using statistical package 'STATA", Correlated panels corrected standard error Model was employed to test the relationship between leverage and their potential determinants. Multiple regressions were also used to determine the most important explanatory variables affecting the capital structure of pharmaceutical firms in Bangladesh. In connection to this, the general model for this study, as is mostly found in the existing literature is represented by;

$$
Y_{i, t}=\alpha+\beta X_{i, t}+\varepsilon_{i, t}
$$

The subscript i representing the cross-sectional dimension and $t$ denote the time-series dimension. The left-hand variable which is the firm's debt ratios represents the dependent variable in the model. Xi,t includes a number of independent variables estimated by the model .

Therefore, the model for this study, was based on the one used by Amidu (2007) with some modification to explain the relationships between leverage and determinants of capital structure as shown below.

$$
L E V_{i, t}=\beta_{0}+\beta_{1} P R_{i, t}+\beta_{2} T A_{i, t}+\beta_{3} G R_{i, t}+\beta_{4} O L_{i, t}+\beta_{5} S Z_{i, t}+\beta_{6} L Q_{i, t}+\varepsilon_{i t}
$$

Where:

$$
\begin{aligned}
& \mathrm{PR}=\text { Profitability } \\
& \text { TA }=\text { Tangibility } \\
& \text { GR }=\text { Growth } \\
& \mathrm{OL}=\text { Operating leverage } \\
& \mathrm{SZ}=\text { Size } \\
& \mathrm{LQ}=\text { Liquidity }
\end{aligned}
$$

Table 1. Indictors of leverage and dependent variables

\begin{tabular}{ll}
\hline Variables & Indicator \\
\hline $\begin{array}{c}\text { Dependent Variable } \\
\text { Leverage }\end{array}$ & Total debt/total asset \\
Independent Variables & \\
Profitability & Ratio of EBIT to total asset \\
Tangibility & Fixed Assets / Total Asset \\
Growth & Annual change in total asset \\
Operating Leverage & EBIT/Operating Revenue \\
Size & Natural Logarithm of Total Asset \\
Liquidity & Liquid assets/ Total Current liability \\
\hline
\end{tabular}


The dataset for this was panel data. Panel (or longitudinal) data are cross-sectional and time-series. There are multiple entities, each of which has repeated measurements at different time periods. Panel data models examine fixed and/or random effects of entity (individual or subject) or time.

\subsection{Determinants of Capital Structure}

There are a large number of potential factors that may have an impact on leverage ratio. These factors include size of the firm, tangibility, profitability, growth, liquidity and operating leverage.

\subsubsection{Profitability}

There are different views regarding the relationship between leverage and profitability according to capital structure theories. Trade of theory predicts that profitable firms would employ more debt because of the tax shield that comes from increased leverage (Myers, 1984).

Bankruptcy costs and agency costs may also encourage profitable funds to take more debt. Highly profitable firms have increased ability to meet the fixed obligation for debt repayment. Therefore, they will have more debt to take advantage of increased tax benefit at more attractive costs of debt. Thus trade off theory suggests a positive relationship between leverage and profitability. However, the pecking order theory of Myers and Majluf (1984) predicts the opposite. It predicts a negative relationship between leverage and profitability. Highly profitable firms are able to generate more internal funds through retained earnings which leads to less debt.

\subsubsection{Growth}

According to pecking order theory firms with high growth will tend to look to external funds to finance the growth. Myers (1977) confirms this and concludes that firms with a higher proportion of their market value accounted for by growth opportunity will have debt capacity. Therefore, it is expected that there is a positive relationship between growth and leverage ratio

\subsubsection{Tangibility}

Tangibility is an important determinant of the capital structure of a firm. The trade-off theory predicts a positive relation between tangibility and debt levels. Tangible assets work as a collateral of borrowed fund. High tangibility therefore leads to increased borrowing ability. According to pecking order theory, a firm with more tangible assets will have less information asymmetry problem. Less information asymmetry problems imply a lower dependence on debt and a preference to equity. Thus it suggests a negative relationship between leverage and tangibility (Harris \& Raviv, 1991). The ratio of tangible assets to total assets is selected as a proxy for tangibility of assets.

\subsubsection{Size}

According to trade-off theory, firm size could be an inverse proxy for the probability of the bankruptcy costs. Larger firms are found to be more diversified and fail less often. They can lower costs (relative to firm value) in the case of bankruptcy. Larger firms are more likely to have higher debt capacity and are expected to borrow more to maximize the tax benefit from debt because of diversification (Titman \& Wessels, 1988). Therefore, size has a positive effect on leverage. Size can be regarded as a proxy for information asymmetry between managers and outside investors.They should be more capable of issuing equity which is more sensitive to information asymmetry and have lower debt (Rajan \& Zingales, 1995). This suggests that pecking order theory predicts a negative association between leverage and the size of firm.

\subsubsection{Liquidity}

There are two different opinions on the association between liquidity and capital structure: First view implies a positive significant relation that is consistent with trade off theory. Companies with more liquidity (more current assets) tend to use more external borrowing, because of their ability in paying off their liabilities. Second view points to a negative significant relation that is consistent with the pecking order theory, arguing that companies with more liquidity will decrease external financing, relying on their internal funds. Thus, liquidity ratios may have a mixed effect on the capital structure decisions. Most of the previous studies, confirm the negative relation, (Ahmed et al., 2010; Najjar \& Petrov, 2011). Hence, liquidity is expected to have negative impact on leverage ratio.

\subsubsection{Operating Leverage}

Operating leverage is measured by the use of fixed costs in the operation of the firms. The operating leverage has been calculated by dividing the EBIT by Operating Revenue. Higher operating leverage leads to greater risk. So a firm with high operating leverage takes lower amount of debt to reduce further risk. Therefore we expect a 
negative relationship between operating leverage and debt ratio.

\section{Imperial Analysis and Interpretations of Results}

\subsection{Descriptive Statistics}

The study examined the determinants of capital structure for eight Pharmaceuticals firms over the time period from (2009-2013). The descriptive statistics of the dependent and explanatory variables for the sample Pharmaceuticals were summarized in Table 2. The total observation for the each dependent and explanatory variable was 40 . Moreover, the figure also shows the mean, standard deviation, minimum and maximum values for the dependent and independent variables.

Table 2. Descriptive statistics of capital structure determinants

\begin{tabular}{llllll}
\hline Variable & Obs & Mean & Std. Dev. & Min & Max \\
\hline Debt Ratio & 40 & 0.2648025 & 0.1972546 & 0.025 & 0.69 \\
Profitability & 40 & 0.175985 & 0.0981783 & 0.0276 & 0.38 \\
Size & 40 & 8.163875 & 1.464207 & 6.32 & 10.22 \\
Growth & 40 & 0.133675 & 0.1184771 & -0.3 & 0.35 \\
Operating Leverage & 40 & 2.2066 & 2.626042 & 1 & 11.78 \\
Liquidity & 40 & 1.485 & 0.6562481 & 0.73 & 3.11 \\
Tangibility & 40 & 0.456135 & 0.1965348 & 0.15 & 0.75 \\
\hline
\end{tabular}

Leverage equals total debt to total asset. Pharmaceuticals firm's mean leverage ratio was 26.48 percent with the standard deviation of 19.73 percent. This explains that firms use more than 26 percent debt and almost $73 \%$ assets of the Pharmaceutical firms are equity financed on an average. Range of using debt as part of capital structure varied from 2.5 percent to 69 percent with standard deviation of 10.73 percent. It shows that use of debt is quite dissimilar among the firms.

Profitable firms have stronger base to face odd scenarios i.e. financial distress and can continue their operation more smoothly than unprofitable firms in long run. Profitability, determined as the ratio of operating profit to total assets, generates a mean value of 17.60 percent which indicates that the operating return to assets is 17.60 percent on an average for this industry. Standard deviation was 9.81 percent and the sample ranged from 2.78 percent to 38 percent. It shows a greater variation in profitability among the pharmaceutical firms in Bangladesh.

Tangibility is calculated by fixed assets by total assets. Table shows that the mean tangibility is 45.61 percent. That means the entire firm's fixed asset consists almost 46 percent of total assets on average. The fixed assets to total asset for the sample were ranged from 15 percent to 75 percent with standard deviation of 19.65 percent.

Growth was measured as the annual percentage change in total asset. Table shows that the mean growth rate is 13.37 percent and standard deviation is 11.85 percent. It means that the total assets of the firms during the last five years increased at an average rate of 13.37 percent. During this period, growth rate ranged from -30 percent to 35 percent.

Here, firm's size is determined by the natural logarithms of total assets. From the table it can be seen that firm's mean size is represented by 8.16 with standard deviation of 1.46 . It means natural logarithms of average total asset of the sample firms during the five year is 8.16. Natural logarithms of total assets for the sample ranged from 6.32 to 10.22 .

Besides, for the study sample, liquidity ranged from 73 percent to 311 percent with a mean of 148 percent of the current liability. Firms' operating leverage which was presented by the ratio of operating profit to operating revenue had a mean of 2.21 with a standard deviation of 2.63 .

\subsection{Correlation Analysis}

According to Brooks (2008), the degree of linear relationship between two variables is measured by the correlation between them. Correlation between the explanatory variable and leverage is shown in the table. In order to determine the strength \& direction of the relationship among the independent variables and the leverage, Pearson correlation coefficient was used. 
Table 3. Correlation analysis of capital structure determinants

\begin{tabular}{cccccccc}
\hline & Debt Ratio & Profitability & Size & Growth & Operating Leverage & Liquidity & Tangibility \\
\hline Debt Ratio & 1.0000 & & & & & & \\
Profitability & 0.5824 & 1.0000 & & & & & \\
Size & -0.6429 & -0.6253 & 1.0000 & & & & \\
Growth & -0.3159 & -0.3531 & 0.2191 & 1.0000 & & & \\
Operating Leverage & -0.3151 & -0.523 & 0.4223 & 0.0545 & 1.0000 & -0.319 & 1.0000 \\
Liquidity & 0.0256 & -0.0129 & 0.2239 & -0.1397 & -0.1427 & 0.2388 & 1.0000 \\
Tangibility & -0.7786 & -0.5316 & 0.5887 & 0.3505 & & \\
\hline
\end{tabular}

The correlation matrix shows the relationship among the variables. Table shows that leverage (dependent variable) was negatively correlated to size, growth, operating leverage and tangibility. It indicates that firm with higher size, growth; operating leverage and tangible assets are less interested to use more debt as part of their capital structure. However profitability and liquidity are positively correlated to dependent variable debt to equity ratio.

From the results whether multicollinearity problem is present or not can also be determined. Since the correlation between the any two independent variables is not more than 80 percent it can be said that there is no multicollinearity problem in the dataset. It can be determined in another way also. The highest correlation coefficient between the independent variable and dependent variable (Leverage to Tangibility) in the data set is almost 77 percent. Since no value of correlation among the independent variables (such as profitability to tangibility, operating leverage to liquidity) is more than 77 percent in the results, it can be said that there is no existence of multicollinearity problem in the dataset.

\subsection{Test for Heteroskedasticity Problem}

Panel data model was used in this study and random effect, fixed effects model are the tools which could be used to determine the associations among the variables. But in using these models there is greater probability of presence of heteroskedasticity problem in the dataset. So at first finding out whether the problems are present or not is necessary and for this, test of heteroskedasticity is needed.

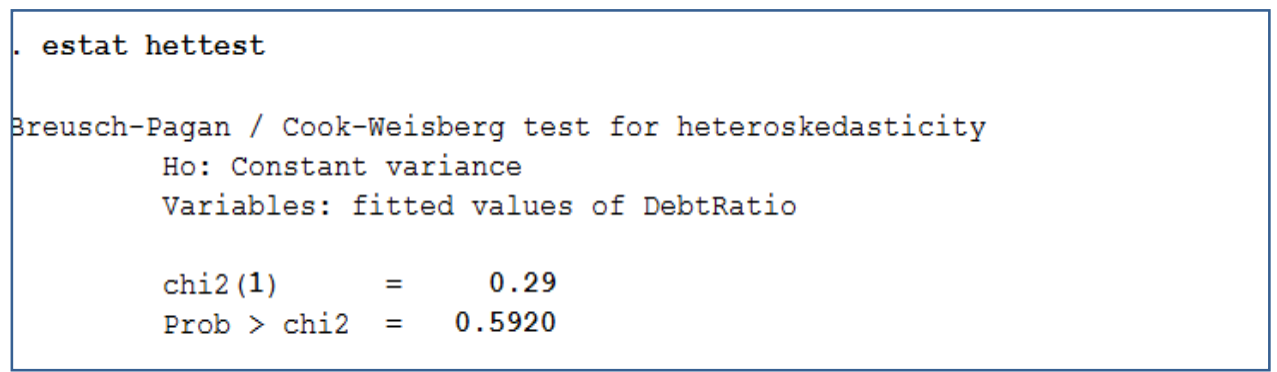

Figure 1. Heteroskedasticity problem detection

Breusch-Pagan/Cook-Weisberg test is used to identify heteroskedasticity problem. Here null hypothesis is that the sample has constant variance. At $5 \%$ level of significance, the chi2 value is not statistically significant. Therefore we fail to reject the null hypothesis. So there is no heteroskedasticity problem in the data set. The data set is homoskedastic.

\subsection{Results of Regression Analysis}

We used Correlated panels corrected standard error Model to measure the impact of explanatory variables on the dependent variables. Correlated panels corrected standard error Model is a regression technique. It is applicable for panel data which automatically corrects any autocorrelation and heteroskedasticity problem in the model. 
Table 4. Regression output

\begin{tabular}{lcccc}
\hline Debt Ratio & Coef. & Panel-corrected Std. Err. & $\mathbf{Z}$ & $\mathbf{P}>|\mathbf{z}|$ \\
\hline Profitability & -0.5068922 & 0.1638742 & $-3.09^{*}$ & 0.002 \\
Size & 0.0063951 & 0.014506 & 0.44 & 0.659 \\
Growth & -0.0157484 & 0.1456739 & -0.11 & 0.914 \\
Operating Leverage & -0.044516 & 0.0102401 & $-4.35^{*}$ & 0.000 \\
Liquidity & 0.0208298 & 0.0169473 & 1.23 & 0.219 \\
Tangibility & -1.04223 & 0.1206135 & $-8.64^{*}$ & 0.000 \\
cons & 0.846599 & 0.0857482 & 9.87 & 0.000 \\
\hline
\end{tabular}

* represents $1 \%$ level of significance.

The results from the test indicate that profitability, operating leverage and tangibility are strongly statistically significant at $1 \%$ level of significance. The result also show that profitability, operating leverage and tangibility are negatively related to leverage or debt to equity ratio but size, growth and liquidity ( $\mathrm{p}$-value $=65.9 \%, 91.4 \%$, $21.9 \%$ ) are statistically insignificant at $10 \%$ level of significance.

\subsection{Discussions of Results}

The following discussions present the relationship between explanatory variables and leverage ratio.

\subsubsection{Profitability}

The regression model depicts that profitability is statistically significant (p-value 0.00) at 1 percent level of significance and negatively related to debt to equity ratio (leverage).This result is congruent to our theoretical expectations. It implies that every one percent change in Pharmaceuticals firm's profitability keeping the other thing constant has a resultant change of 0.50 percent on the leverage in opposite direction. This result reveals that highly profitable Pharmaceuticals firms go for less debt to their capital structure as they have enough accumulated internal reserves in the form of retained earnings. They prefer internal financing to external financing for investments.

The result of this study is consistent with the pecking order theory. Moreover, the negative relationship between profitability and leverage was supported by the majority of empirical studies. Rajan and Zingales (1995), Amidu (2007), and Caglayan and Sak (2010) were some of them.

\subsubsection{Tangibility}

The table shows that tangibility is negatively related to debt ratio. Results of the regression model suggest that tangibility is strongly statistically significant (p-value 0.00 ) at 1 percent level of significance. The result implies that with every one percent change in Pharmaceuticals firm's tangibility keeping the other thing constant has a resultant change of $1.04 \%$ on the leverage in the opposite direction. This significant negative relationship between tangibility and leverage is supported by the findings of Harris and Raviv (1991). The results suggest that Bangladeshi pharmaceutical firms which have more fixed assets as a percentage of total asset tend to go for less debt.

\subsubsection{Growth}

Results of the regression model (negative coefficient) indicates that growth has negative relationship to leverage and it is statistically insignificant at 10 percent significance level (since p-value is 0.914). It explains that Pharmaceuticals firms in Bangladesh do not want to go for extra interest burden during their growing period. The negative relationship is consistent with the trade of theory.

\subsubsection{Size}

The results of regression model indicate that size has positive relationship to the leverage. However this variable is but statistically insignificant ( $\mathrm{p}$-value is 0.649 ) at 10 percent level of significance. This implies that every one percent change (increase or decrease) in the firm's size keeping the other thing constant had a resultant change of 0.63 percent on the leverage in the same direction. The results suggest that the bigger firms need more external funds to use. Capital providers prefer to lend to large firms as these firms are supposed to have lower earnings volatility and lower risk level. This positive relation of size \& leverage is consistent with the empirical findings of Titman and Wessels (1988), Rajan and Zingales (1995), Booth et al. (2001), Amidu (2007), and Caglayan and Sak (2010). 


\subsubsection{Liquidity}

The results of regression model in table indicated that liquidity had a positive but statistically insignificant ( $p$-value $=0.219)$ relationship with leverage. This positive sign shows a direct relationship between the liquidity and leverage for Bangladeshi pharmaceuticals firms.

\subsubsection{Operating Leverage}

Theoretically operating leverage should have a negative impact on leverage. The results of regression model in table indicated that operating leverage had negative relationship with the leverage of firms, and it is statistically significant ( $p$-value $=0.00$ ) at $1 \%$ level. This implies that every one percent change (increase or decrease) in the firms operating leverage keeping the other thing constant had a resultant change of 4.45 percent on the leverage in the opposite direction. It means that for pharmaceuticals industry in Bangladesh, firms with higher degree of operating leverage take less amount of debt because high operating leverage already increased the risk level of the firm.

The different expectations for the relationship between leverage and explanatory variables for the static trade-off, pecking order, and agency cost theories are presented in following Table. This table also provides the empirical findings of this study.

Table 5. Theoretical expectations and empirical findings

\begin{tabular}{lcccccc}
\hline \multirow{2}{*}{ Explanatory Variables } & \multicolumn{3}{c}{ Theoretical expectations } & Empirical & \multirow{2}{*}{ Supporting Theory } \\
\cline { 2 - 5 } & Trade-Off & Pecking Order & Agency Cost & Findings & \\
\hline Profitability & + & - & $?$ & + & - & Pecking Order \\
Size & + & - & $+/-$ & + & Trade-Off \\
Tangibility & + & $+/$ & - & - & Pecking Order \\
Growth & - & - & $?$ & + & Trade-Off \\
Liquidity & + & - & $?$ & - & Pecking Order \\
Operating Leverage & + & & & & \\
\hline
\end{tabular}

It is evident from the table that 3 variables i.e. profitability, tangibility and operating leverage follow the pecking order theory while other 3 variables i.e. size, growth and liquidity follow the static trade-off theory. However size and growth variables are consistent with agency cost theory. In a nutshell it can be concluded that the static trade-off theory and pecking order theory are the most relevant capital structure theories for determining the factors affecting the capital structure of pharmaceutical firms in Bangladesh.

\section{Summary and Conclusions}

The main objective of this study was to examine the relationship between leverage and firm specific (profitability, tangibility, growth, size, liquidity and operating leverage) determinants of capital structure decision. To achieve the intended objective the study used quantitative methods. The quantitative data were collected through document reviews from a sample of 8 pharmaceuticals firms over the time period from 2009-2013. The collected data were analyzed by employing Correlated panels corrected standard error model using statistical package 'STATA 13'.

The multiple regression model suggests that $82.26 \%$ of the variation in leverage ratio can be explained by the variation in 6 firm specific independent variables. That means only $17.74 \%$ variation in dependent variables was unexplained by the model. The overall model was statistically significant.

A discussion of the result indicates that tangibility, profitability and operating leverage were statistically significant factors (at $1 \%$ level) that determine the capital structure of pharmaceutical firms in Bangladesh. However, discussions of the result indicate that size, growth and liquidity were not an important explanatory variable of leverage in Bangladeshi pharmaceutical industry.

Another important observation of this study is that both static trade-off model and packing order theory help describe the capital structure of pharmaceutical company as because the empirical findings are consistent with these 2 models. The study will provide important policy implications for financial managers in choosing appropriate capital structure for the company to maximize value of the firm. In addition to that the researchers can utilize the results of the study for further analysis and also incorporate other factors like agency cost, bankruptcy risk, managerial actions, financial flexibility etc. to achieve a better view of the capital structure of different firms in Bangladesh. 


\section{References}

Ahmed, N., Ahmad, Z., \& Ahmed, I. (2010). Determinants of capital structure: A case of life insurance sector of Pakistan. European Journal of Economics, Finance and Administrative Sciences, 24, 7-12.

Akintoye, I. R. (2008). Effect of capital structure on firms' performance: The Nigerian experience. European Journal of Economics, Finance and Administrative Sciences, 10, 233- 243.

Bayeh, A. (2011). Capital structure determinants: An empirical study on insurance industry in Ethiopia. Master's thesis, Addis Ababa University.

Bradley, M., Jarrell, G. A., \& Kim, E. H. (1984). On the existence of an optimal capital structure: Theory and evidence. Journal of Finance, 39, 857-878. http://dx.doi.org/10.1111/j.1540-6261.1984.tb03680.x

Buferna, F., Bangassa, K., \& Hodgkinson, L. (2005). Determinants of capital structure evidence from Libya. Research Paper Series, No. 2005/08, pp. 1-31.

Chowdhury, M. U. (2004). Capital Structure Determinants: Evidence from Japan \& Bangladesh. Journal of Business Studies, xxv(1), 23-45.

Flannery, M. J., \& Rangan, K. P. (2006). Partial adjustment toward target capital structures. Journal of Financial Economics, 79, 469-506. http://dx.doi.org/10.1016/j.jfineco.2005.03.004

Gropp, R., \& Heider, F. (2009). The determinants of bank capital structure.

Hausman, D. M. (1998). Causal asymmetries. New York: Cambridge University Press. http://dx.doi.org/10.1017/CBO9780511663710

Huang, G., \& Song, F. M. (2005). The determinants of capital structure: Evidence from China. China Economic Review, 17, 14-36. http://dx.doi.org/10.1016/j.chieco.2005.02.007

Jensen, M. (1986). The agency costs of free cash flow: Corporate finance and takeovers. American Economic Review, 76(2), 323-329.

Jensen, M., \& Meckling, W. (1976). Theory of the firm: Managerial behavior, agency costs and ownership $\begin{array}{lllll}\text { structure. Journal of } & \text { Financial }\end{array}$ http://dx.doi.org/10.1016/0304-405X(76)90026-X

Lima, M. (2009). An insight into the capital structure determinants of the pharmaceutical companies in Bangladesh. GBMF Conference, 2009.

Modigliani, F., \& Miller, M. (1958). The cost of capital, corporation finance and the theory of investment. American Economic Review, 48, 261-297.

Modigliani, F., \& Miller, M. (1963). The Corporate Income Taxes and the Cost of Capital: A Correction. American Economic Review, 53(3), 433-443.

Myers, S. C., \& Majluf, N. (1984). Corporate financing and investment decisions when firm have information that investors do not have. Journal of Financial Economics, 13, 187-221. http://dx.doi.org/10.1016/0304-405X(84)90023-0

Najjar, N., \& Petrov, K. (2011). Capital structure of insurance companies in Bahrain. National Journal of Business and Management, 6(11). http://dx.doi.org/10.5539/ijbm.v6n11p138

Rajan, R. G., \& Zingales, L (1995). What do we know about capital structure? Some evidence from international data. Journal of Finance, 50, 1421-1460. http://dx.doi.org/10.1111/j.1540-6261.1995.tb05184.x

Rao, N. V., Al-Yahyaee, K. H. M., \& Syed, L. A. M. (2007). Capital structure and financial performance: Evidence from Oman. Indian Journal of Economics and Business, 1-23.

Ross, S. A., Westerfield, R. W., \& Jaffe, J. (2002). Corporate finance. McGraw - Hill, USA.

Sayeed, A. M. (2011). The Determinants of Capital Structure for Selected Bangladeshi listed companies. International Review of Business Research Papers, 7(2), 21-36.

Semu, S. Z. (2010). Impact of reducing loan by Ethiopian banks on their own performance. Master's thesis, University of South Africa.

Siddiqui, S. S. (2012). Capital Structure Determinants of Non-Bank Financial Institutions (NBFIs) in Bangladesh. World Review of Business Research, 2(1), 60-78.

Titman, S., \& Wessels, R. (1988). The determinants of capital structure choice. Journal of Finance, 43(1), 1-19. 
http://dx.doi.org/10.1111/j.1540-6261.1988.tb02585.x

Weston, J. F., \& Copeland, T. E. (1998). Managerial Finance (2nd ed.). New York: CBS College Publishing.

Zeitun, R., \& Tian, G. G. (2007). Capital structure and corporate performance: Evidence from Jordan. Australasian Accounting, Business \& Finance Journal, 1(4), 40-61.

\section{Appendix 1}

\section{Regression output from STATA}

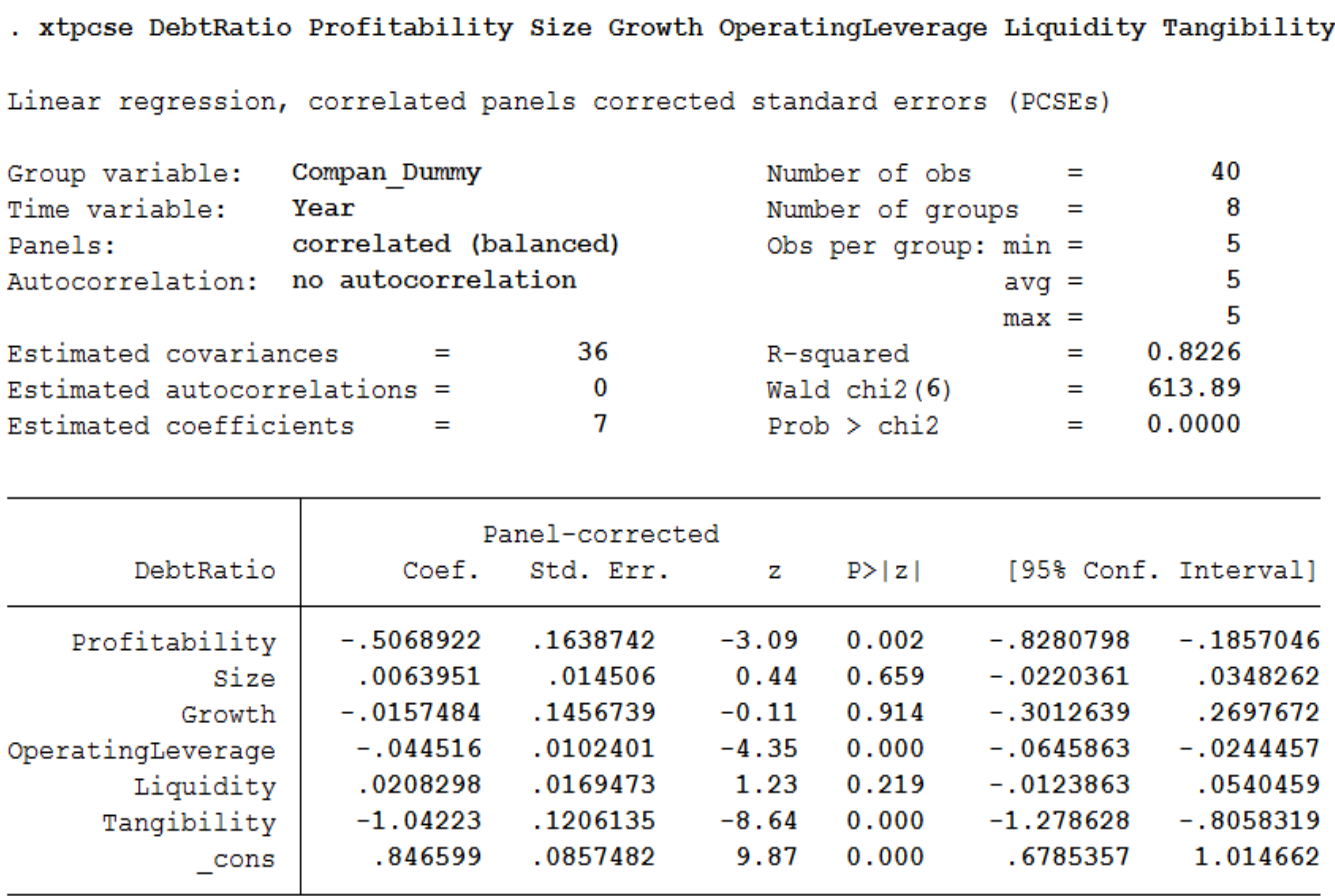

\section{Copyrights}

Copyright for this article is retained by the author(s), with first publication rights granted to the journal.

This is an open-access article distributed under the terms and conditions of the Creative Commons Attribution license (http://creativecommons.org/licenses/by/3.0/). 